\title{
Stumbling in the Dark: Ray Bradbury's Pedestrian and the Politics of the Night
}

\author{
Matthew Beaumont
}

But if a man walk in the night, he stumbleth, because there is no light in him.

John 11: 10

'The Pedestrian' (1951) is a science-fiction short story by Ray Bradbury about a man who, after nightfall, roams aimlessly and compulsively about the silent streets of a nameless metropolis. It is set in a totalitarian society at the midpoint of the twentyfirst century, roughly a hundred years after it was written. In Bradbury's dystopian parable - it is a satirical portrait of Los Angeles that, because of its bleak attack on urban alienation, continues to resonate - the supremacy of the automobile has made it impossible in practice to be a pedestrian. Indeed, the police state has in effect proscribed pedestrianism. So, in this far from distant future, no one travels by foot. Except, of course, the Pedestrian.

'To enter out into that silence that was the city at eight o'clock of a misty evening in November,' the story begins, 'to put your feet upon that buckling concrete walk, to step over grassy seams and make your way, hands in pockets, through the silences, that was what Mr. Leonard Mead most dearly loved to do.' Mead, whose name gently reinforces the pastoral associations of those 'grassy seams' that furrow the pavement, generally begins his nightwalks at an intersection, because from there he can 'peer down long moonlit avenues of sidewalk in four directions, deciding which way to go'. But the point is that, 'alone in this world of A.D. 2053, or as good as alone,' it doesn't matter which direction he takes. ${ }^{1}$ So he relishes selecting a route at random, thinking of it as a 'path' rather than an avenue or road. He is halfconsciously creating what Paul Farley and Michael Symmons Roberts, in their recent celebration of the 'edgelands' that characterize the uncertain border between cities and the surrounding countryside, have classified as 'desire paths'. These are 'lines of footfall worn into the ground' that transform the ordered, centralized spaces of the city into secret pockets; and that, in so doing, offer a 'subtle resistance to the dead hand of the planner'. ${ }^{2}$

Once he has decided on a direction, Mead strides off along his desire path, then, at once purposeful and purposeless. 'Sometimes he would walk for hours and miles and return only at midnight to his house.' Mead has never encountered another living creature on these nighttime walks. Nor has he so much as glimpsed another pedestrian in the daytime, because people travel exclusively by car. 'In ten years of walking by night or day, for thousands of miles, he had never met another person walking, not once in all that time.' ${ }^{3}$ The reason for the eerie solitude of the city at night is that everyone else has carefully secluded themselves in their living rooms in order to stare blankly and obediently at television screens. So if there is no political curfew in place in Bradbury's dystopian society then this is because a kind of cultural curfew renders it superfluous. 
Crossing and re-crossing the city at night on foot, aimlessly reclaiming the freedom of its streets from automobiles, Bradbury's Pedestrian is identifiable as the scion of a distinct tradition of urban rebellion or resistance, the dissident tradition of the nightwalker.

The distant origins of the so-called common night-walker's identity lie in late thirteenth-century England, when Edward I introduced the Statute of Winchester as a means of enforcing the curfew that prevailed at that time throughout the nation's towns and cities. This 'nightwalker statute', as it was known, then became central to the colonial law instituted in North America in the late seventeenth century. In 1660, colonial law made provision that the state's night watchmen should 'examine all Night Walkers, after ten of the clock at Night (unless they be known peaceable inhabitants) to enquire whither they are going, and what their business is'. If the individual accosted could not 'give not Reasonable Satisfaction to the Watchman or constable' making this enquiry they were liable to being arrested and taken before the Magistrate, who would ask them 'to give satisfaction, for being abroad at that time of night'. ${ }^{4}$

In urban settlements throughout North America there was in the early modern period no right to the night, particularly for plebeians. Almost by definition, the poor could not 'give satisfaction for being abroad' after dark. In the streets at night the itinerant were an inherent threat to society. Today, there are still residues of this situation, as there were in the 1950s. Indeed, in some places in the United States, the 'common nightwalker' remains on the statute books, where it indicates a vagrant as well as a streetwalker or prostitute. 'An idle or dissolute person who roams about at late or unusual hours and is unable to account for his presence' is the definition of a nightwalker offered by two legal commentators who summarized a number of relevant statutes in the 1960s. ${ }^{5}$ The ordinance against vagrants in Jacksonville, Florida, for instance, includes a reference to nightwalkers. The state, in its infinite leniency, doesn't construe a single night's wandering as criminal, necessarily. 'Only "habitual" wanderers, or "common night walkers",' the authors of a legal textbook explain, 'are criminalized.' 'We know, however, from experience,' they rather drily add, 'that sleepless people often walk at night." ${ }^{6}$ The sleepless, the homeless and the hopeless, then, are all susceptible to this archaic charge.

It is against this legal background - and the persistent suspicion about solitary people who inhabit the streets at night that, historically, it has sponsored - that Bradbury's portrait of a nocturnal pedestrian trapped in a dystopian cityscape demands to be interpreted. In spite of the passage of more than three hundred years, since the origins of colonial law in North America, nightwalking remains a socially transgressive activity. For Bradbury, writing in the 1950s, it potentially also has political implications. 'The Pedestrian' is an affirmation of the heterodox politics of the night, which 'has always been the time for daylight's dispossessed,' as Bryan Palmer writes, '- the deviant, the dissident, the different. ${ }^{7}$ The Pedestrian's footsteps, echoing on empty, darkened pavements, interrupt the ominous silence of the totalitarian city, which insists that its inhabitants remain visible but inaudible at all times.

'The Pedestrian' was written at a time when domestic life in North America was being dramatically altered not only by the rise of the automobile but, at its interior, the 
rise of television. The number of TV sets in the US leapt from 7000 in 1946 to 50 million in 1950. Bradbury was evidently deeply troubled by these developments, and his dystopian dream of an oppressive society that uses television to ensure a docile, depoliticized population is comparable to Theodor Adorno's contemporaneous critique of the so-called culture industry. Adorno, who had lived in Los Angeles throughout the 1940s, argued in 'How to Look at Television' (1954) that this technology had already become a crucial medium of psychological control. 'The repetitiveness, the selfsameness, and the ubiquity of modern mass culture,' he insisted, 'tend to make for automatized reactions and to weaken the forces of individual resistance." 8

More recently, in his powerful critique of 'the 24/7 control society', Jonathan Crary includes a diatribe - manifestly influenced by the Frankfurt School - against the sedative and immobilizing effects of the 'mass diffusion of television in the 1950s'. Applied like a medicinal balm to a population made febrile by the traumatic experience of World War II, he claims, television 'was the omnipresent antidote to shock'. It insinuated masses of people into 'extended states of relative immobilization': 'Hundreds of millions of individuals precipitously began spending many hours of every day and night sitting, more or less stationary, in close proximity to flickering, light-emitting objects.' Crary's retrospect of the psychic and social impact of the new technology in this epoch itself reads like science fiction. But his insights are penetrating. 'In spite of more uprooted and transient lifestyles following the war,' he notes, 'television's effects were anti-nomadic: individuals are fixed in place, partitioned from one another, and emptied of political effectiveness. ${ }^{\prime 9}$ This is the immediate context for 'The Pedestrian'. Strolling in the streets at night becomes a means of reclaiming, for a moment, a sense of autonomy in an administered world.

In Bradbury's story, the city is a cemetery, its houses like tombstones that, as Mead ambles past them, are sometimes troubled by 'sudden gray phantoms' - in the form of the cold, cathode images flickering in rooms that so far have not been curtained off from the street. Despite the stupefied state of these citizens, Mead is careful not to make a noise outside their homes. Indeed, 'long ago he had wisely changed to sneakers when strolling at night, because the dogs in intermittent squads would parallel his journey with barkings if he wore hard heels, and lights might click on and faces appear and an entire street be startled by the passing of a lone figure, himself, in the early November evening. ${ }^{10}$ He has to be surreptitious, as those sneakers indicate. He is conscious that nightwalking is unacceptable because - semicriminalized as it is in this society - it constitutes an act of what might be called 'excarceration'. ${ }^{11}$ If the television shows to which other citizens have become addicted are escapist, the Pedestrian's nightwalking instead represents, simply, a form of escape. It is a flight; a fugue, at once psychogenic and sociogenic. But its affirmation of the nomadic is also, implicitly, a critique of the static, dessicated and depoliticized culture of the United States in the 1950s. It is a refusal of reification.

On the particular evening narrated by Bradbury in 'The Pedestrian', Mead heads in the direction of 'the hidden sea'. It is a crisply cold autumnal night, and as he passes their houses he whispers his contempt for the people watching comedies and cowboy movies behind closed doors. Occasionally, he catches at a leaf - 'examining its skeletal pattern in the infrequent lamplights' and 'smelling its rusty smell'. ${ }^{12} \mathrm{He}$ feels acutely sensitive to the faint residues of a non-mechanized existence that can still be found amid the city's alienated conditions. This is evidently one of the reasons the 
Pedestrian repairs to the streets at night. It reminds him he is alive, transforming the metropolis into a sort of biosphere. Nightwalking de-alienates Mead's perception of the quotidian world, which in contradistinction to that of the other citizens has not been relentlessly deadened either by the automated routines of the daytime or the anaesthetic effects of television. In one sense, then, 'The Pedestrian' is a celebration of - the pedestrian. It affirms the ordinary, insignificant details of life that, like the leaf, have been discarded by this increasingly attenuated, if not skeletalized society, and left to rust.

In his minatory reflections on television, Adorno warned that 'people may not only lose true insight into reality, but ultimately their very capacity for life experience may be dulled by the constant wearing of blue and pink spectacles' ${ }^{13}$ Reality, according to Adorno, was in danger of becoming a kind of 3D illusion in California in the 1950s. In the solitude of the city at night, Mead's experience of the physical life about him, even though it has been debased and deformed, can momentarily be made to seem disalienated. At nighttime the city is immediate. It is no longer seen from afar - mediated by television, which literally means sight at a distance - but from close up. For the Pedestrian, nightwalking effectively participates in what the Russian Formalists called the poetic function. In a famous article from 1917, Viktor Shklovsky wrote that it is the point of art 'to return sensation to our limbs' - 'to make us feel objects, to make a stone feel stony. ${ }^{14}$ Encountering the remnants of physical life alone at night, Mead experiences them as if for the first time. He grasps the leaf in its leafiness, suddenly sensitive to its skeletal pattern and its rustiness.

In the night, the metropolis itself appears magically estranged to the Pedestrian. It comes to seem so alien that it no longer feels alienated. Its dystopian landscape paradoxically adumbrates the faint promise of a utopian future. At one point, he stops in a 'silent and long and empty' street and fantasizes that the city too has been silenced and emptied. Indeed, that it is no longer a city at all: 'If he closed his eyes and stood very still, frozen, he could imagine himself upon the center of a plain, a wintry, windless American desert with no house in a thousand miles, and only dry riverbeds, the streets, for company. ${ }^{15}$ This prophetic vision not simply of a deserted city, but of a city that, perhaps after the collapse of civilization itself, has been reduced to no more than the desert that, at its foundation, it originally reclaimed, can be found back as far as the Bible: 'Thy holy cities are a wilderness, Zion is a wilderness, Jerusalem a desolation' (Isaiah 64: 10).

It is an apocalyptic vision that shapes a number of important precursors to the dystopian fiction of the twentieth century, from Daniel Defoe's Journal of the Plague Year (1722) to Richard Jefferies' After London (1885). It appears, for example, to unsettling effect in Oliver Goldsmith's The Citizen of the World (1760-61), a collection of letters about contemporary England purportedly sent by 'a Chinese philosopher' corresponding with 'his friends in the East'. In one of these letters, the celebrated author of The Deserted Village (1770) - a poem about the brutal dispossession, in the late eighteenth-century English countryside, of the labouring class - describes walking about in the emptied streets of London at 2 a.m. The Deserted City. 'There will come a time,' Goldsmith comments, when the 'temporary solitude' of the metropolis at night, 'may be made continual, and the city itself, like its inhabitants, fade away, and leave a desert in its room. ${ }^{16}$ For Mead, as for Goldsmith's Chinese philosopher, the depopulated metropolis at night (the deserted city) anticipates a post-apocalyptic future in which civilization itself, hopelessly corrupt, has been almost completely effaced (the desert city). 
Setting off again, the Pedestrian momentarily loses his footing on a jagged piece of paving stone. 'He stumbled over a particularly uneven section of sidewalk,' Bradbury writes. The pavement has been displaced, incipiently, by the subterranean presence of plant life. Weeds, as Richard Mabey has reminded us, 'green over the dereliction we have created' and 'insinuate the idea of wild nature into places otherwise quite shorn of it. ${ }^{17}$ Bradbury's narrator observes that the city's endless plains of cement appear already to be eroding - 'vanishing under flowers and grass'. ${ }^{18} \mathrm{He}$ scrutinizes the ruderals secretly reappearing on the roadsides of the totally administered city. This is the nocturnal equivalent - it is a strikingly literal as well as political one - of what Benjamin famously characterized as 'botanizing on the asphalt'. ${ }^{19}$

In the 'grassy seams' of the nighttime streets, as Bradbury calls them, which are signs of irrepressible organic life gradually erupting through the surface of the neglected city, Mead glimpses the ecology of an emergent apocalypse. The first phase of the city's apocalyptic destruction, or dissolution, is perhaps a creeping pastoral collapse. Organic life will corrode the manmade forms, the concrete and steel, with which the city is encased. This fantasy recalls the description of Forli in Mary Shelley's The Last Man (1826), another precursor of twentieth-century dystopian fiction. For there, in spite of the city's 'desolation', the result of its abrupt depopulation after a plague, or because of it, the hero momentarily finds pleasure in the 'grassy streets' that have appeared. ${ }^{20}$ Like this precedent, 'The Pedestrian' is a vengeful fantasy of what Mike Davis has referred to as 'the monstrous vegetative powers of feral nature'. ${ }^{21}$

The final phase of the apocalypse implicit in the Pedestrian's dream of the future is no doubt the kind of cataclysmic destruction that, as in the case of an atomic bomb, might reduce the city to little more than a 'wintry, windless American desert with no house in a thousand miles'. In this image, Bradbury evokes what Fredric Jameson has called the 'pleasures of dystopia'. ${ }^{22}$ The pleasures of dystopia can be descried in the surreptitious, almost unacceptable thrills to be derived from the images of depopulation that accompany the representation of a catastrophe. Jefferies gives satisfying expression to them in After London, where his unsentimental narrator, reflecting on the implosion of the metropolis after a natural disaster, records that it 'was after all only of brick, and when the ivy grew over and trees and shrubs sprang up, and, lastly, the waters underneath burst in, this huge metropolis was soon overthrown'. ${ }^{23}$ Bradbury's destructive or self-destructive hopes for the dystopian metropolis he describes in 'The Pedestrian' are comparable to those of Jefferies. After Los Angeles.

It is only by imagining total social and ecological destruction that an alternative to the rational administration of totalitarian society can be envisaged. For the Pedestrian, Bradbury suggests, this destruction, this alternative, only becomes imaginable because, in stumbling over the uneven paving stone, he is suddenly made conscious of the subterranean operation of a force that cannot be administered. Nature itself - notwithstanding the potentially terminal impact of climate change that has been ascertained since the 1950s - cannot be administered out of existence.

But in Bradbury's narrative there is after all a political curfew as well as the cultural one enforced by the addiction of the masses to television. Mead's apocalyptic imagining as he steals across the city under the partial protection of the dark - his ecological fugue - is suddenly interrupted by the appearance of a car that flashes 'a 
fierce white cone of light upon him'. It is a police car. No logo or slogan is stenciled on its side; but, if there had been, it might have read, 'We Own the Night' - this was the tagline of the NYPD's Street Crimes Unit, disbanded after the brutal shooting of an unarmed immigrant in 1999. In fact, this is the city's only police car. 'Crime was ebbing,' Bradbury explains; 'there was no need now for the police, save for this one lone car wandering and wandering the empty streets.' Meandering along the roads at night, the police car is Mead's mechanical double. It mimics his aimless movements, cruelly mocking the limits of his freedom.

In a 'metallic whisper' - which makes it clear that it is automated and contains no policemen - the vehicle interrogates the Pedestrian. It asks him first for his profession. Mead is a professional writer, as he confesses. The machine's phonographic voice offers a clinical, if laconic, response to this admission: 'No profession.' By 2053, television has all but rendered books redundant. The disembodied voice of the state proceeds to question Mead further:

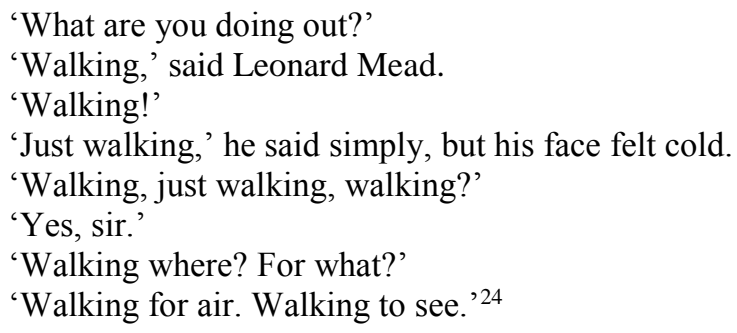

Dissatisfied with this reason that is no reason at all - Mead's statement is a tautological one that constitutes an affront to a society defined, as Herbert Marcuse might have put it, by 'the rational character of its irrationality' - the police machine coerces him into the back seat of the vehicle. ${ }^{25}$ He will be transported in this 'little cell', he is informed, 'to the Psychiatric Center for Research on Regressive Tendencies'. In the totalitarian state imagined by Bradbury, then, to walk in the city at night is not only to transgress; it is to regress. Nightwalking, according to this logic, is intrinsically deviant, even atavistic. It transpires that the Pedestrian's final nightwalk is a flight that concludes, as psychogenic fugues often do, in a psychiatric institution. ${ }^{26}$ The act of excarceration ends in incarceration.

And so the narrative ends, abruptly: 'The car moved down the empty riverbed streets and off away, leaving the empty streets with the empty sidewalks, and no sound and no motion all the rest of the chill November. ${ }^{, 27}$ Indeed, for all time, it is to be presumed. For Leonard Mead, who has carefully tried to curate the remaining residues of the alienated city's humanity, is effectively its Last Man. Only the unevenness of the pavement, secretly undermined by feral plants, is a cause for hope. At the end of 'The Pedestrian', it still seems possible that Nature itself, at some fardistant date, in the form of an ecological apocalypse, might still be a stumbling block to the totally administered society of the twenty-first century. If only for the reader, those empty streets that in the dark look like cracked, dried riverbeds are desire paths.

In the story of Lazarus in St. John's Gospel, Jesus observes that 'if any man walk in the day, he stumbleth not, because he seeth the light of this world'. He adds that, if instead 'a man walk in the night, he stumbleth, because there is no light in him.' (John 11: 9-10). Mead stumbles when he takes the aimless walk in the night described by 
Bradbury not because there is no light in him but for precisely the opposition reason; because, alone in this totalitarian conurbation, he does contain an inner light.

The other citizens are bathed in the feverish half-light that leaks from the television sets in front of which they lifelessly sit; Mead seeks illumination in the darkness. In this respect, he is like one of those persecuted sixteenth-century mystics who were driven by the surveillance operations of the post-medieval Church to find spiritual consolation in the night, and who valorized not simply light in the dark but 'the darkness that illuminates'. This phrase is taken from John of the Cross, perhaps the most famous of these mystics, who was forced by his experiences as a prisoner in an almost lightless cell to identify faith, in an apophatic inversion of traditional theological assumptions, with the darkness of midnight rather than the light of midday. 'The more the soul is darkened,' John affirmed, 'the greater is the light that comes into it. ${ }^{, 28}$ For Mead, as for the theologians of the night, the dark has become a place of refuge and a site of possible redemption.

Obversely, illumination is associated with oppression, as when he is immobilized by the beam of the police car that arrests him. The 'light of this world', in Christ's formulation, is an agent of post-Enlightenment oppression. By contrast, the absence of light offers a form of freedom. Strolling through the streets of Los Angeles after dusk is, for Mead, a spiritual, if not religious, ritual. Reclaiming the city at night, when no one else is about, he redeems it; and in so doing he retains a fragile hold on his humanity. He is the post-contemporary equivalent of a benandante, or 'good walker', one of those medieval Italian peasants who set out at night to do battle with witches. In the eyes of the authorities these benign walkers were malign walkers. Mead's sacred walks, like those of the benandanti, who claimed their nighttime activities took place in a dream-like state between sleeping and waking, are finally punished as satanic. ${ }^{29}$

Mead's humanity consists in being, mere being - meaning, not a state of subsistence, like the numbed citizens connected to their television screens as if to life-support machines, but being for its own sake. The nightwalker walks because he likes to breathe, as he admits, and because he likes to see; but he also walks because he likes to walk. He just walks. The nightwalker does not walk from one point to another in order to reach a destination. Hence it does not matter which direction he takes when he stands at the crossroads at the commencement of the night. He simply walks, opening himself up to the empty city.

In the night, Bradbury indicates, the Pedestrian likes to stands at a silent intersection, the junction at which the city's main roads meet, precisely because in the day it is 'a thunderous surge of cars, the gas stations open, a great insect rustling and a ceaseless jockeying for position as the scarab-beetles, a faint incense puttering from their exhausts, skimmed homeward to the far directions.' At nighttime, this intersection becomes a somnambulist's dream space. The roads are 'like streams in a dry season, all stone and bed and moon radiance'. ${ }^{30}$ This is the landscape of the 'moonlit enchanted night' celebrated by the German Romantic poet Ludwig Tieck. It is the realm of 'irrealism' in which Michael Löwy has discovered 'a critical attitude towards the disenchanted modern world, illuminated by the blinding sun of instrumental rationality'. 31

The Pedestrian does not commute, then, in contrast to the other citizens of this future, because commuting, travelling directly from one place to another, far from commuting him, or transforming his identity, reinforces his sense of sameness. The 
commuter, as Rachel Bowlby observes, is 'a traveller along straight, known lines, not an aimless, curious drifter'. ${ }^{32}$ It is precisely in order to be commuted, or spiritually transmuted, that the Pedestrian does not commute. His routes through the city are the opposite of a commute; they are a more or less conscious indictment of its instrumental regime. Mead's pedestrianism, at once calculated and spontaneous, defies the metrics of the commute. The nightwalker sets himself against the rhythms of the city's traffic, the frenetic movements of its commodities and people. He is a romantic anti-capitalist who nonetheless remains passionately in love with the modern metropolis. He refuses the city in the name of the city.

In this context, nightwalking is a radical activity, in both the political and more literal senses of the term (it brings to light the root of his being). Or, to put it in the terms of the police state depicted by Bradbury, it is both a transgressive and a regressive tendency. It is inherently countercultural, as the fact that Mead is finally incarcerated demonstrates; but it is also an activity that, to the scandal of an automated, mechanized culture, goes back to the root of what it is to be human. Walking can in this latter sense be identified with what Marx called men and women's 'species-life', the fundamental properties of their physical and spiritual existence that define their humanity. ${ }^{33}$ It is not constituted by exchange value but usevalue. Nightwalking, for Mead, is not instrumental; it is an end in itself. Something like a negative dialectics of the nightwalk is thus made visible in Bradbury's narrative. As in Samuel Beckett's universe, according to Adorno, the empty nocturnal cityscape of 'The Pedestrian' is 'the negative imprint of the administered world'. ${ }^{34}$ It is a negation of the negation; the negative imprint of a negative imprint.

Nightwalking constitutes a rejection, conscious or unconscious, of the tedious logic of the diurnal city. It renounces the predictable trajectories, the teleologies, of what William Blake, in 'London' (1794), called its 'chartered streets'; and it does so in the name of what Blake called 'midnight streets'. It glories in the contingent, the tangential. Walking, for Mead, satisfies a human need. And it is this that renders it unacceptable in a society like the one portrayed by Bradbury, where human needs have become so attenuated that they can be satisfied, for almost all of the population, by automobiles and TV comedies.

In so far as it is simply an allegory of oppression, 'The Pedestrian' was probably influenced by 'The Revolt of the Pedestrians' (1928), a short story by the sciencefiction novelist David H. Keller. Far more reactionary than Bradbury's fantasy, Keller's dystopia centres on a society in which the Automobilists, human beings whose legs have progressively atrophied because they are so dependent on motorized transport, oppress an embattled minority of enlightened Pedestrians.

But 'The Pedestrian' was also the product of a psychological obsession that reaches back into Bradbury's childhood. Aged sixteen, some three years after his family had moved to Los Angeles, he witnessed a car crash involving several fatalities, and became traumatized. 'I walked home holding onto walls and trees,' as he put it in a later description of this incident. He subsequently elaborated his almost pathological opposition to the automobile into a political position, writing an anonymous editorial for his high-school magazine, when he was no more than eighteen, entitled 'Pedestrian becomes Freak among Modern Inventions'. Subsequently, Bradbury recapitulated the theme of this article on numerous occasions: 'I would replace cars wherever possible with buses, monorails, rapid trains 
- whatever it takes to make pedestrians the center of our society again, and cities worthwhile enough for pedestrians to live in. ${ }^{35}$ He never held a driving license.

'The Pedestrian' was however more immediately precipitated by Bradbury's Kafkaesque encounter with the police one night in 1949. As Bradbury described it, he and a friend happened to be walking along Wilshire Boulevard in Los Angeles, after nightfall, deep in conversation with one another, 'when a police car pulled up and an officer stepped out to ask what we were doing.' Bradbury responded: 'Putting one foot in front of the other.' This didn't impress the policeman, so Bradbury added, 'Breathing the air, talking, conversing, walking.' The officer remained mystified... 'Walking, eh? 'Just walking?' Eventually, after giving it some thought, he dismissed the two nightwalkers, telling them not to do it again. It was this 'Alice in Wonderland encounter', as Bradbury characterized it, which provided the impetus for 'The Pedestrian', 36

Bradbury had experienced this kind of incident several times before this date, as he subsequently testified: 'I had been stopped on numerous occasions for walking at night, for being a pedestrian.' As far back as 1941, for example, the police had accosted him and another friend some time after midnight in Pershing Square. He extrapolated 'The Pedestrian' from these experiences, developing a sort of politics of pedestrianism in the process. As Bradbury's biographer has argued, he 'had come to see the pedestrian as a threshold or indicator species among urban dwellers - if the rights of the pedestrian were threatened, this would represent an early indicator that basic freedoms would soon be at risk. ${ }^{37}$

'The Pedestrian', for its part, sparked the composition of Fahrenheit 451 (1953), probably Bradbury's most famous dystopian fiction (not least because François Truffaut adapted it for the cinema in 1966). Soon after finding a publisher for the short story, as Bradbury has explained, he decided to take his 'midnight criminal stroller out for another job around the city'. ${ }^{38}$

Fahrenheit 451 describes a totalitarian society - its population too is pacified if not completely sedated by television - in which literature is forbidden. In this future, it is the function of firemen not to extinguish fires but to burn books. The protagonist of Bradbury's humanist fable, Montag, is a fireman who, after meeting an enlightened young woman, starts to rebel against this regime. In the end, he escapes from the city, where he has become a fugitive, and joins a community of exiles who, living like hobos, have memorized the contents of classic books in order to preserve the remnants of civilization from the state. At the close of the novel, in a far-off cataclysm, the metropolis from which Montag has escaped, along with other American cities, is abruptly flattened by atomic bombs; and he imagines the 5 a.m. bus 'on its way from one desolation to another', its destination suddenly 'meaningless', 'its point of departure changed from metropolis to junkyard.' ${ }^{39}$

Originally entitled 'Long After Midnight', traces of the nightwalking episode that is central to 'The Pedestrian' can be discerned in Fahrenheit 451. The novel begins with a commute - though in this case one that has a genuinely transformative effect. Changing out of his protective clothing after a routine shift spent torching a house that contains books, Montag leaves the fire station in which he works, walks out 'along the midnight street' that leads to the metro, and takes a train back to the suburbs. Recently, when returning to his home from the station, he has sensed someone else's presence on the street at night; but, on checking, he has seen 'only the white, unused, buckling sidewalk'. As in 'The Pedestrian', which also includes 
images of buckling sidewalks, this is a city that, at night, is almost as uninhabited as a lunar landscape. On this occasion, though, he encounters a seventeen-year-old called Clarisse (her name emblematic of the role she plays in enlightening and hence radicalizing him). In a calculated attempt to meet him, she is strolling apparently casually along the 'moonlit pavement'. ${ }^{40}$ This is the domain, once again, of the enchanted city at night, though in this case the street is also the site of a kind of political or spiritual seduction.

Intrigued, Montag asks the girl what she is doing 'out so late wandering around', and she tells him, with a simplicity that charms him, that it is 'a nice time of night to walk': 'I like to smell things and look at things, and sometime stay up all night, walking, and watch the sun rise.' Like Leonard Mead, she invokes the city's poetic function at night. They walk together on the 'silvered pavement'; and she gives him a detailed account of her family, which consists of book-lovers and intellectuals i.e., deviants. In particular, she relates that her uncle has twice been arrested, once for driving too slowly on a highway ('He drove forty miles an hour and they jailed him for two days'), and once 'for being a pedestrian'. ${ }^{41}$

Clarisse disappears shortly after this episode, and the reader assumes that she has either been detained or murdered by the authorities. But by this time the clandestine nightwalks that Montag shared with her, which have been unimpeachably chaste, have had the requisite effect on his political consciousness. As the fire chief later contemptuously puts it, she appeared in his life 'like the midnight sun', upsetting the natural order. ${ }^{42}$ She concentrated or reflected the darkness that illuminates, to formulate it in mystical terms. In the central section of the novel, Bradbury charts his protagonist's deepening disaffection with the barbaric regime of which he has hitherto been an obedient agent. It is a disaffection that can be measured by the number of books that, instead of destroying, he secretly accumulates at home.

It is once his cache of books has been discovered that the state ruthlessly pursues him. At this point, the moonlit city that had opened up to him on his perambulations with Clarisse is transformed into an obscure labyrinth from which he must desperately escape. 'Watch for a man running,' the police announce to vigilant citizens, "watch for the running man ... watch for a man alone on foot. ${ }^{43}$ The nightwalker has been forced to go on the run.

As the narrative of Fahrenheit 451 starts to accelerate to its conclusion, Montag furtively enters a gas station in order to clean himself ('Men as a rule do not visit gas stations at night on foot,' as the authors of an article in an American journal of criminology drily remarked in the mid-1930s, in the course of their reflections on a case concerning 'night prowlers'). ${ }^{44}$ Then he steals out 'into the darkness' and stands in silence looking onto a vast, empty boulevard. He must traverse this road in order to elude his pursuers, even though it will make him highly visible (not least because of streetlamps that seem 'as bright and revealing as the midday sun'). ${ }^{45} \mathrm{He}$ has to reach the safety of a dark alley he can see across the road.

It is a richly dramatic scene taken straight from the noir cinema of the 1940s and 1950s, and it offers a reminder that Truffaut's fatal mistake when he filmed the novel in the mid-1960s was to disregard this noir element and instead set all the exterior action in the daytime. If only Fahrenheit 451 had looked more like Alphaville (1965). In Jean-Luc Godard's far more atmospheric science-fiction film, the futuristic city of the film's title constitutes the centre of a technocratic society that is supposedly entering 'the Civilization of Light', one in which emotions have been 
criminalized and citizens have been made the 'slaves of probability'. But Godard's cinematographer Raoul Coutard deliberately portrays it as a city of darkness. He dramatizes this irony - this noirony, as it might be called - in a series of cool, cynical shots of slickened, crepuscular streets in a dystopian Paris set at nighttime.

After leaving the gas station, Bradbury's protagonist commences 'his little walk' across the deserted road, which looks like a 'vast concrete river': 'He put his right foot out and then his left foot and then his right. He walked on the empty avenue.' But he is conscious that he can be seen by a half-concealed vehicle with its headlights on three blocks distant from him. The car accelerates in his direction and he starts to run. Then he abruptly reduces his pace so as not to attract attention: 'Walk, that's it, walk, walk.' But the car continues to hurtle closer and closer to him, a hostile emissary of the technological culture from which he has recently exiled himself. 'He began to shuffle idiotically and talk to himself and then he broke and just ran. He put out his legs as far as they would go and down and then far out again and down and back and out and down and back.' His motions, as the clumsy syncopations of this sentence indicate, are reduced to their basic mechanical components (in 'The Pedestrian', it will be recalled, travelling by foot is classified as a 'regressive tendency'). Montag plunges on across the road, 'yelling in concrete emptiness', and, like Mead, stumbles. And falls. ${ }^{46}$

But, at the last moment, the car misses him. Instead of the police, it contains thrill-seekers: 'children out for a long night of roaring five or six hundred miles in a few moonlit hours'. They must have accidentally seen a 'very extraordinary sight', he thinks - 'a man strolling' - and decided to eliminate him simply for the hell of it. ${ }^{47}$ They hadn't killed him because he happened to fall. A fortunate fall, then. He speculates, though, that it might have been kids like this, and not the police, that killed Clarisse simply because she liked to walk at night. Perhaps she was not a political martyr after all. Perhaps she was just another senseless victim of a mechanized society careering out of control.

Montag staggers onto the far kerb, 'telling each foot to go and keep going.' Then he hides 'in the safety of the dark alley for which he had set out,' standing 'shivering in the night' as the youths in the car circle back for him. Soon he has to move. The state continues to track him as a fugitive, instructing all citizens to leave their television sets in order to stand at their front doors and identify his fleeing outline: 'He couldn't be missed! The only man running alone in the night city, the only man proving his legs!' 48

Montag manages to escape, of course; first up the river, then along a desire path that takes the form of a forgotten train track. In the end, he finds the other refugees from this totalitarian society - exiled intellectuals who have adopted the identities of the books they have memorized ('I am Plato's Republic' etc.). One of them has a portable television, so the former fireman is able to see a triumphant live broadcast of his own death, dramatized by the state for the benefit of the docile masses sitting semi-comatose in their homes. How is this spectacle possible? It transpires that the authorities have targeted 'some poor fellow [who] is out for a walk' in the night and, through some deft manipulations of the camera, persuaded the audience that he is Montag. Any social outcast will do. 'Don't think the police don't know the habits of queer ducks like that,' he is told by one of the other fugitives, 'men who walk mornings for the hell of it, or for reasons of insomnia. ${ }^{, 49}$ This innocent pedestrian is tracked down and exterminated on screen. In Bradbury's dystopian imagination, once again, the nightwalker, a 'midnight criminal stroller', is the quintessential heroic outcast. 
The anonymous nightwalker made to stand in for Montag by the state when it stages its retribution as a television spectacle is a scapegoat. Montag is a scapegoat too. And so is Leonard Mead. In Bradbury's totalitarian future, these nightwalkers are like the pharmakoi, the scapegoats of ancient Greek religion: criminalized but nonetheless sacred outsiders whose social function is to incarnate the guilt of the community from which they have been emblematically excluded. In the dystopian narratives in which they feature, they are therefore innately double, at once sanctified and accursed; the 'symbol of both transgression and redemption', in Terry Eagleton's terms. As such, they represent a homeopathic form of hope. At the end of 'The Pedestrian', the reader pities Mead when the police deport him in silence to the Psychiatric Center for Research on Regressive Tendencies (which functions as an ancient zone of exclusion that has been relocated inside the city's precincts).

As Eagleton has argued, compassion for the pharmakos is a form of identification that has the effect of displacing feelings of outrage and disgust onto the social order that has victimized him:

\footnotetext{
The scapegoat, itself beyond speech and sociability, become a judgement on that order in its very being, embodying what it excludes, a sign of the humanity which it expels as so much poison. It is in this sense that it bears the seeds of revolutionary agency in its sheer passivity; for anything still active and engaged, however dissidently, would still be complicit with the polis, speaking its language and thus unable to put it into question as a whole. Only the silence of the scapegoat will do this. ${ }^{50}$
}

When Mead closes his eyes and stands stock still in the street at night, picturing the city as a desert plain, he is this scapegoat. At the end of the story, 'the empty streets with the empty sidewalks,' which are disturbed by 'no sound and no motion', represent a materialization of his mute, passive protest. The city itself, in its silence, and through its cracked sidewalks, constitutes a concrete refusal of the totalitarian logic that has deformed it. It has been reduced to a state of Beckettian resistance. But the nocturnal city's bare life, and the one man who inhabits the night, haunting it like the undead, points beyond itself to an apocalypse from which it might ultimately be rebuilt.

Perhaps the most significant moment in 'The Pedestrian', as I have already implied, is when Mead misses his step on the warped or buckled pavement: 'He stumbled over a particularly uneven section of sidewalk.' If there are no lost steps, as André Breton once professed, then there are no missed steps either. Mead's stumble momentarily points to the utopian remainder embedded or hidden in this dystopia. The loose stone, a token of both past and future that protrudes into the present, is the skandalon; meaning, a stumbling block, one which will become the cornerstone of some new social order. In the language of Ernst Bloch, it is a utopian surplus or excess, symbolic of the Not Yet. ${ }^{51}$ It marks the site from which this apparently indestructible totalitarian society will start to undermine itself and collapse. The nightwalker also marks a point of deconstruction. He too is a scandal.

According to St. John's Gospel, to walk in the night is by definition to stumble, to admit to having fallen or lapsed: 'But if a man walk in the night, he stumbleth, because there is no light in him.' The verb 'to stumble' comes from the Old Norse meaning to grope and trip in the dark. To walk in the night is to be benighted, morally blinded. Only those who have no light in them walk at night. But in spite of stumbling, or because of it (it is another fortunate fall), Bradbury's 
Pedestrian finds in the night, in the darkness that illuminates, an inner light. In this sense, and in spite of his incarceration at the end of the narrative, Mead embodies hope. Excluded from the diurnal city, like the sixteenth-century mystics who reclaimed the dark for spiritual purposes, he is forced to find redemption in the night. In this respect, the Pedestrian himself, in his stubborn refusal of the rules of Bradbury's totalitarian society, dramatized in his nightwalking, is this society's stumbling block or skandalon

Nightwalking is, in a dual sense, scandalous: the rambling and stumbling of the nightwalker is socially unacceptable; but, if he has been scapegoated, historically, then his aimless activity is, potentially at least, the cornerstone of a different kind of society.

${ }^{1}$ Ray Bradbury, 'The Pedestrian,' in Stories, Vol. 2 (London: HarperCollins, 2003), p. 569.

${ }^{2}$ Paul Farley and Michael Symmons Roberts, Edgelands: Journeys into England's True Wilderness (London: Jonathan Cape, 2011), p. 23.

${ }^{3}$ Bradbury, 'The Pedestrian,' p. 569.

${ }^{4}$ William Henry Whitmore, The Colonial Laws of Massachusetts. Reprinted from the Edition of 1660, With the Supplements to 1672 (Boston: City Council of Boston, 1889), pp. 198-9.

${ }^{5}$ Quoted in Martha Grace Duncan, Romantic Outlaws, Beloved Prisons: The Unconscious Meanings of Crime and Punishment (New York: New York University Press, 1996), p. 172.

${ }^{6}$ David C. Brody, James R. Acker and Wayne A. Logan, Criminal Law (Gaithersburg, Maryland: Aspen, 2001), p. 63.

${ }^{7}$ Bryan D. Palmer, Cultures of Darkness: Night Travels in the History of Transgression (New York: Monthly Review Press, 2000), pp. 16-17.

${ }^{8}$ Theodor W. Adorno, 'How to Look at Television,' in The Culture Industry: Selected Essays on Mass Culture, ed. J.M. Bernstein (London: Routledge, 1991), p. 138. Incidentally, in a larger political context, I agree with Terry Eagleton that 'the dystopian view that the typical citizen of advanced capitalism is the doped telly viewer is a myth, as the ruling class itself is uncomfortably aware.' See Ideology: An Introduction (London: Verso, 1991), p. 42.

9 Jonathan Crary, 24/7: Late Capitalism and the Ends of Sleep (London: Verso, 2013), pp. 79-81.

${ }^{10}$ Bradbury, 'The Pedestrian,' p. 569.

${ }^{11}$ I take this formulation from Peter Linebaugh, The London Hanged: Crime and Civil Society in the Eighteenth Century, second edition (London: Verso, 2006), p. 23.

${ }^{12}$ Bradbury, 'The Pedestrian,' pp. 569-70.

13 Adorno, 'How to Look at Television,' p. 147.

${ }^{14}$ Viktor Shklovsky, 'Art as Device,' in Theory of Prose, trans. Benjamin Sher (Champaign, IL: Dalkey Archive Press, 1990), p. 6.

${ }^{15}$ Bradbury, 'The Pedestrian,' p. 570.

${ }^{16}$ Oliver Goldsmith, The Citizen of the World: or, Letters from a Chinese

Philosopher, Residing in England, to His Friends in the East (London, 1782), pp. 216-7.

${ }^{17}$ Richard Mabey, Weeds: How Vagabond Plants Gatecrashed Civilization and Changed the Way We Think about Nature (London: Profile, 2010), p. 20. 
${ }^{18}$ Bradbury, 'The Pedestrian,' p. 570.

${ }^{19}$ Benjamin, The Arcades Project, p. 372.

${ }^{20}$ Mary Shelley, The Last Man, ed. Morton D. Paley (Oxford: Oxford University Press, 1998), p. 455. For more on the representation of empty cities, and on the utopian appeal of what, after Benjamin, I have called 'socially empty space', see Matthew Beaumont, The Spectre of Utopia: Utopian and Science Fictions at the Fin de Siècle (Oxford: Peter Lang, 2012), Chapter 4.

${ }^{21}$ Mike Davis, Dead Cities (New York: New Press, 2002), p. 370.

${ }^{22}$ Fredric Jameson, 'Then You Are Them,' London Review of Books 31: 17 (10 September 2009), p. 7.

${ }^{23}$ Richard Jefferies, After London: or, Wild England (Oxford: Oxford University Press, 1980), p. 36.

${ }^{24}$ Bradbury, 'The Pedestrian,' p. 571.

${ }^{25}$ Herbert Marcuse, One-Dimensional Man (London: Abacus, 1972), p. 21.

${ }^{26}$ On psychogenic fugue, see Ian Hacking, Mad Travelers: Reflections on the Reality of Transient Mental Illnesses (Cambridge, MA: Harvard University Press, 1998); and Matthew Beaumont, The Spectre of Utopia, Chapter 3.

${ }^{27}$ Bradbury, 'The Pedestrian,' p. 572.

${ }^{28}$ See Craig Koslofsky, Evening's Empire: A History of the Night in Early Modern Europe (Cambridge: Cambridge University Press, 2011), pp. 59, 79.

${ }^{29}$ See Carlo Ginzburg, The Night Battles: Witchcraft and Agrarian Cults in the Sixteenth and Seventeenth Centuries, trans. John and Anne Tedeschi (Baltimore: Johns Hopkins University Press, 1983).

${ }^{30}$ Bradbury, 'The Pedestrian,' p. 570.

${ }^{31}$ Michael Löwy, 'The Current of Critical Irrealism,' in Adventures in Realism, ed. Matthew Beaumont (Oxford: Blackwell, 2007), p. 198.

${ }^{32}$ Rachel Bowlby, 'Commuting,' in Restless Cities, ed. Matthew Beaumont and Gregory Dart (London: Verso, 2010), p. 52.

${ }^{33}$ See Karl Marx, Economic and Philosophical Manuscripts (London: Lawrence \& Wishart, 1977), pp. 67-9.

${ }^{34}$ Theodor W. Adorno, Aesthetic Theory, ed. Gretel Adorno and Rolf Tiedemann, trans. Robert Hullot-Kentor (London: Athlone Press, 1997), p. 31.

${ }^{35}$ See 'Playboy Interview: Ray Bradbury,' Playboy 43: 5 (May 1996), pp. 47-56, 14950 .

${ }^{36}$ Ray Bradbury, 'Burning Bright: An Afterword,' in Fahrenheit 451, anniversary edition (London: HarperCollins, 2003), p. 177.

${ }^{37}$ Jonathan R. Eller, Becoming Ray Bradbury (Urbana, Ill.: University of Illinois Press, 2011), p. 239. No doubt Bob Dylan would understand Bradbury's alarm. In 2009, he was arrested late one afternoon while wandering alone in the rain, some distance from his tour bus. A local resident reported 'an eccentric-looking old man' behaving suspiciously. As this incident demonstrates, the isolated, slightly tattered individual on the street embodies a spontaneous refusal of the suburban values that prevail in tightly curtained interiors.

${ }^{38}$ Ray Bradbury, 'Burning Bright: An Afterword,' in Fahrenheit 451, anniversary edition (London: HarperCollins, 2003), p. 178.

${ }^{39}$ Ray Bradbury, Fahrenheit 451, anniversary edition (London: HarperCollins, 2003), p. 166.

${ }^{40}$ Bradbury, Fahrenheit 451, pp. 12-13.

${ }^{41}$ Bradbury, Fahrenheit 451, pp. 14, 16. 
42 Bradbury, Fahrenheit 451, p. 121.

${ }^{43}$ Bradbury, Fahrenheit 451, p. 132.

${ }^{44}$ Andrew A. Bruce and Shurl Rosmarin, 'The Gunman and his Gun,' Journal of

Criminal Law and Criminology (Northwestern), 24 (1933-4), p. 537.

${ }^{45}$ Bradbury, Fahrenheit 451, pp. 133-4.

${ }^{46}$ Bradbury, Fahrenheit 451, pp. 134-5.

${ }^{47}$ Bradbury, Fahrenheit 451, p. 136.

${ }^{48}$ Bradbury, Fahrenheit 451, pp. 136-7, 146.

${ }^{49}$ Bradbury, Fahrenheit 451, p. 156.

${ }^{50}$ Terry Eagleton, Sweet Violence: The Idea of the Tragic (Oxford: Blackwell, 2003), p. 279.

${ }^{51}$ See Ernst Bloch, The Principle of Hope, Vol. 1, trans. Neville Plaice, Stephen Plaice and Paul Knight (Cambridge, MA: MIT Press, 1995), p. 144. 